\title{
DESIGN OF SAFETY REAR IMPACT GUARD FOR HEAVY DUTY VEHICLE
}

\author{
Prof. A. D. Kachare, Prof. M.M. Bidwe \\ Assistant Professor, Department of Mechanical Engineering, \\ Dr. V.V.P. College of Engineering, Vilad Ghat, Ahmednagar, Maharashtra.
}

\begin{abstract}
This paper is about design and fabrication of rear safety impact guard for heavy duty vehicle. Nowadays the problem of accident is a very acute in highway transportation. Traffic accident leads to loss of life and property. We cannot avoid accidents completely but impact of accident can be reduced by applying safety measures and safety instrument. Safety impact guard is one of the safety instruments which can reduce collision impact at rear end collision when accident occurs. Also provide safety against under ride crashes which causes due to passenger vehicle collides with the truck or trailer. Proposed design of safety impact guard includes crushing element as force destroying material. Another aim of this paper is to reduce the height of safety impact guard from ground so that the truck under ride crashes should be avoided. We can save the life and prevent the loss of property. The objective of this entire paper would be of possible design of rear impact guard which provides safety against rear end collision. Also in proposed design of safety impact guard the pressure relief valve is introduced which act as force absorbing element. When rear end collision occurs then the force or energy or impact is absorbed due to action of PRV.
\end{abstract}

Keywords-Accident; Safety Guard; Rear End; Collision; Damper; Impact

Table 1. Number of Accidents and Number of Persons Involved: 2001 To 2009[1]

\begin{tabular}{|c|l|l|l|l|c|}
\hline & \multicolumn{2}{|l|}{ No. of Accident } & \multicolumn{2}{l|}{$\begin{array}{l}\text { No. of Persons } \\
\text { Affected }\end{array}$} & Accident severity \\
\hline Year & $\begin{array}{l}\text { Total } \\
\text { Accident }\end{array}$ & $\begin{array}{l}\text { Fatal } \\
\text { Accident }\end{array}$ & $\begin{array}{l}\text { Persons } \\
\text { Killed }\end{array}$ & $\begin{array}{l}\text { Persons } \\
\text { Injured }\end{array}$ & $\begin{array}{c}\text { (No. of persons } \\
\text { Killed per 100 accidents) }\end{array}$ \\
\hline 2005 & $4,39,255$ & 83,491 & 94,968 & $4,65,282$ & 22 \\
\hline 2006 & 4,60920 & 93,917 & $1,05,749$ & $4,96,481$ & 23 \\
\hline 2007 & $4,79,216$ & $1,01,161$ & $1,14,444$ & $5,13,340$ & 24 \\
\hline 2008 & $4,84,704$ & $1,06,591$ & $1,19,860$ & $5,23,193$ & 25.8 \\
\hline 2009 & $4,86,384$ & $1,10,993$ & $1,25,945$ & $5,15,458$ & \\
\hline
\end{tabular}

Now a day with increasing population number of vehicle owners are also increasing which causes large number of vehicles on the roads. Hence flow pattern of vehicular traffic, presence of mixed traffic along with pedestrians leads to number of serious accidents. At present many safety measures are available which can reduce accidents. The Statistical analysis of accident is carried out periodically at critical locations or road stretches which will help to arrive at suitable measures to effectively decrease accident rates. According to ministry of road transport and highways transport research the increase in rate of accident from year 2005 to year 2009 is shown in the table 1 . In year 2009, 14 accidents occurred per hour in India. As accidents cannot be avoided completely therefore many research is going on to reduce the impact of collision when accident occurs This study work consist design of such safety instrument which can reduce the impact or force when rear end collision occurs known as safety impact guard. When a passenger vehicle collides with a large truck or trailer rig, this mismatch is further aggravated when the passenger vehicle continues beneath the rear or side of the trailer truck. These are called truck under ride crashes and often decapitate the upper half of the passenger vehicle and its occupants. 


\section{International Journal of Engineering Applied Sciences and Technology, 2019 \\ Vol. 4, Issue 5, ISSN No. 2455-2143, Pages 202-209 \\ Published Online September 2019 in IJEAST (http://www.ijeast.com)}

Transport According to Government of India Ministry of Road Transport \& Highways Research Wing the total number of road accidents increased by 2.5 percent. People have lost their lives while travelling, due to a road accident. Trailer, trucks or heavy loaded vehicles are slow in speed due to their load but passenger cars or vehicles speed much greater than the trailer, truck or heavy loaded vehicles. As high speed passenger vehicle collides to heavy loaded vehicle at the rear end the collision force or impact is greater Ground clearance of trucks, trailers or heavy loaded vehicles is greater than passenger cars. Therefore if passenger vehicles could not control their speed then they easily go under the heavy loaded vehicle.
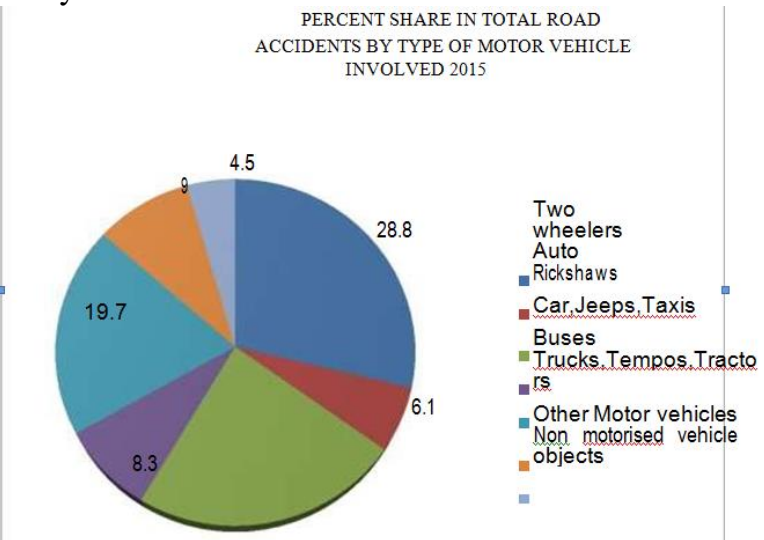

Graph.1 Percent Share in Total Road Accidents by Type of Motor Vehicle Involve

In above pie chart percent share in total road accidents by type of motor involved is specified. In this pie chart if heavy duty vehicles are considered such as the truck, tempos, tractors are causing $19.7 \%$ of total accidents. Therefore conclusion is that large number of accidents is caused due to involvement of heavy duty vehicles.

Rear-end-collision is taken into consideration for this paper. A rear-end accident caused by a commercial truck is more common i.e. collision of a passenger car into a truck is more likely to result in fatalities. Commercial trucks are very large and are often more than 40 times the size of other vehicles on the nation's roadways. Because of this weight discrepancy, they are less maneuverable, slower to start and take longer to stop than passenger vehicles. This combination can lead to catastrophic damage if a collision occurs. Commercial trucks generally are more limited than passenger vehicles when it comes to controlling acceleration, braking and visibility an important factor that contributes to commercial truck accidents. There are two types of rear-end collisions involving these massive trucks. The first, and more common, occurs when a commercial truck strikes a passenger vehicle. The second, and often more deadly, happen when a passenger vehicle strikes a commercial truck. Rear-end collisions caused by commercial trucks are often the direct or indirect result of faulty brakes. Fatigue or a lack of attention was is also often a contributing factor to accidents in these situations.

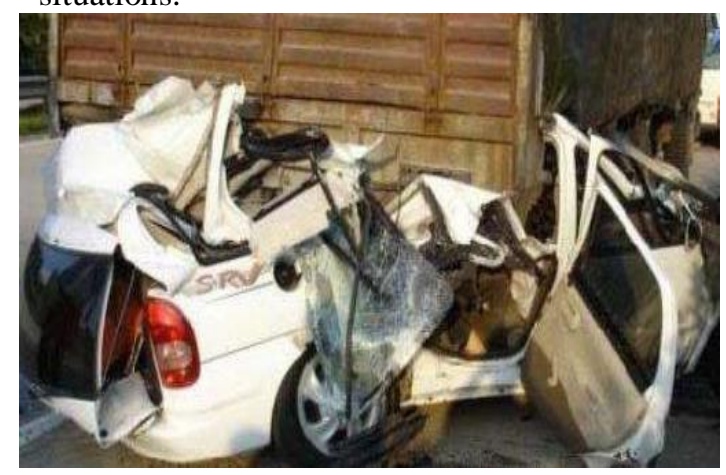

Fig.1 Rear under run collision

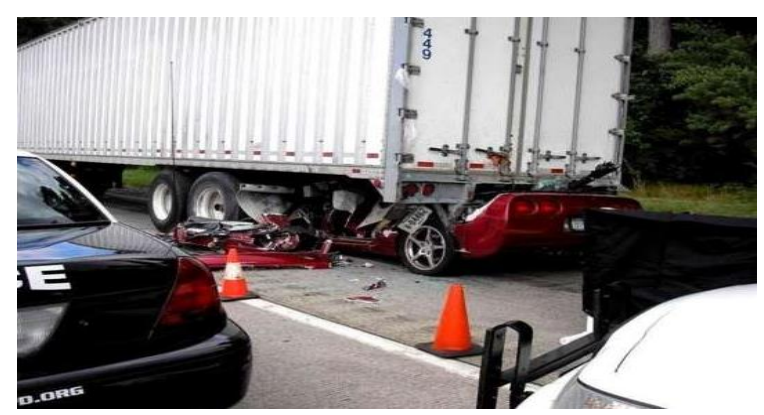

Fig. 2 Under ride Crashes

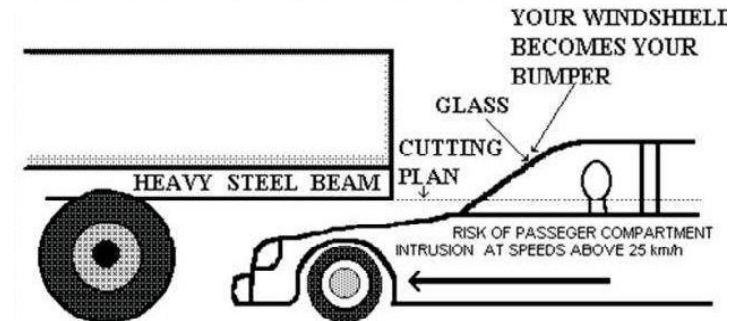

Fig. 3 Position of Vehicle When Crash Is Going To Happen

The second type of rear-end collision, a passenger car striking a commercial truck as shown in the fig. 1 and 2 can be caused by poor lighting conditions and is almost twice as likely to occur at night. Commercial trucks struck by passenger vehicles are often in violation of lighting regulations. This may make trucks more difficult to see and respond to safely. This type of accident has a higher fatality rate because of a phenomenon known as truck under ride. A truck under-ride crash occurs when a 


\section{International Journal of Engineering Applied Sciences and Technology, 2019 Vol. 4, Issue 5, ISSN No. 2455-2143, Pages 202-209 \\ Published Online September 2019 in IJEAST (http://www.ijeast.com)}

passenger vehicles goes partially or wholly under the truck or trailer. Since the passenger vehicle's point of impact is not at the car's bumper, those inside the vehicle are less likely to receive the protections offered by both the bumper and the car's frame. This vulnerability greatly increases the likelihood of death or serious injury to occupants of the vehicle. Most semitrailers are required to have under ride guards. These are steel bars that hang from the backs of trailers to prevent the front of a passenger vehicle from moving underneath during a crash. Earlier research showed that the minimum strength and dimensions required for under ride guards are inadequate. So these cannot prevent the passenger cars and its occupants effectively.

However, not all trucks have under ride guards, not all under ride guards perform as they should in keeping passenger vehicles from sliding under the back end of a truck and getting crushed. Rear impact guards must be able to prevent passenger cars from sliding under the rear end of the truck to the point where the passenger compartment is struck. The current stiff rears under ride guard standards are a safety compromise that does not protect all sizes and weights of current vehicles. They ultimately are too stiff for small vehicles or are too weak for large vehicles. Only energy-absorbing guards provide protection for most sizes and weights of current vehicles and modern designs are cheap and simple to implement.

Rear-end-collision is taken into consideration for this paper. A rear-end accident caused by a commercial truck is more common, collision of a passenger car into a truck is more likely to result in fatalities. Commercial trucks are very large and are often more than 40 times the size of other vehicles on the nation's roadways. Because of this weight discrepancy, they are less maneuverable, slower to start and take longer to stop than passenger vehicles. This combination can lead to catastrophic damage if a collision occurs. Commercial trucks generally are more limited than passenger vehicles when it comes to controlling acceleration, braking and visibility an important factor that contributes to commercial truck accidents. There are two types of rear-end collisions involving these massive trucks. The first, and more common, occurs when a commercial truck strikes a passenger vehicle. The second, and often more deadly, happen when a passenger vehicle strikes a commercial truck. Rear-end collisions caused by commercial trucks are often the direct or indirect result of faulty brakes. Fatigue or a lack of attention was is also often a contributing factor to accidents in these situations. This danger occurs most often on interstates, when drivers traverse long stretches of road without many turns, stops or intersections. As a result, the drivers are more likely to relax their vigilance, thus reducing the drivers' ability to promptly respond to slowed or stopped vehicles.

\section{PROBLEM STATEMENT}

As high speed passenger vehicle collides to heavy loaded vehicle at the rear end the collision force or impact is greater. This force or impact can injure the passenger and also cause damage to vehicles property.

\section{LITERATURE SURVEY}

Dixit Neha S. et.al (2014), a safety impact guard were designed which could reduce collision impact at rear end collision when accident occurs. The safety impact guard included a crushing element as force destroying material. Because of that when rear end collision was occurs the force or energy or impact was destroyed due to crushing action. Another aim of this project is to reduce the height of safety impact guard from ground so that the truck under ride crashes should be avoided. And also the life can be saved and prevent the loss of property. The objective of this entire project would be possible design of rear impact guard which provides safety against rear end collision [1].

Srinivas Bairy (2016), A spring damper system was designed which was the passive safety system. The vehicles should have active safety system which will avoid the accidents as much as possible and passive safety system which will reduce the damage and loss of lives. Passive system will decrease the impact of accident. In this systems spring will store the energy and damper will dissipate the energy. This spring damper system reduces the impact of accident by increasing the time of collision as the spring needs some time to compress it totally. In this to check the amount of reduction in impact force when two bodies collide is analysed with the spring damper system and without the spring damper system. The Impact force is significantly reduced with the spring damper system [2].

José Ricardo et.al (2013), As a consequence of the lack of effective rear underride guards attached to trucks, trailers and semi-trailers, rear underride crashes are responsible for thousands of deaths every year throughout the world. In an attempt to reverse this situation, cooperative work was started between a Brazilian university and local car and truck industries, whose main goals were to design, construct and test reliable underride guards and to present solutions to government authorities. To meet these goals, to date two new retractile underride guards have been designed and three crash tests carried out. Based on the results obtained so far, the Brazilian Association of Technical Standards (ABNT) has elaborated a new Brazilian standard for rear underride guards [3]. 


\section{International Journal of Engineering Applied Sciences and Technology, 2019 \\ Vol. 4, Issue 5, ISSN No. 2455-2143, Pages 202-209 \\ Published Online September 2019 in IJEAST (http://www.ijeast.com)}

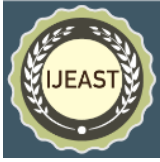

Hassan Galal A. (2014), Too many passengers die or injure every year because of highway accidents. Most of the vehicle manufacturing companies are unable successfully to control this matter. This paper handles the optimal design of a passive spring-damper buffer that can be attached to the vehicle from its front, rear or both sides to avoid catastrophic effects due to collision. The optimization toolbox of MATLAB is used to minimize an absolute error objective function to keep the dynamic motion of the crashing vehicle to below certain level without destroying the standing hit vehicle. A $100 \mathrm{~mm}$ level is set for this dynamic motion. The crashing speed is varied between 20 and $140 \mathrm{~km} / \mathrm{h}$ and a vehicle mass in the range of 1000 to $6000 \mathrm{~kg}$ are considered. The required optimal values of the spring stiffness and damper damping ratio are defined against the crashing speed. The whole process is reduced to the selection of a unit set of buffer parameters to protect crashing small and medium vehicles at speeds $\leq 140 \mathrm{~km} / \mathrm{h}$ with maximum dynamic motions less that the $100 \mathrm{~mm}$ level. This reduces the whole design process to a passive buffer with 88.776 $\mathrm{KN} / \mathrm{m}$ stiffness and a $2250 \mathrm{KN}-\mathrm{s} / \mathrm{m}$ damping coefficient. This avoids the need to active and semi-active expensive techniques [4].

Geoffrey Geldhof (2013), Application of MagnetoRheological (MR) dampers in semi-active vibration dynamics control of a multi-cart system is studied. The dynamics and vibration behavior of a two cart system is investigated mathematically and an experimental test-rig is employed to verify the model, experimentally. The Bouc Wen model is utilized to represent the mathematical behavior of MR damper. Different types of semi-active control strategies as well as passive vibration control technique are implemented in MATLAB and Lab View Compaq-RIO. In the passive case, the damping coefficient remains constant during the operation. While in semi-active control strategy, the main idea is to change (in real time) the passive components characteristics to improve the damping performance. Semi-active control technique can be used for vibration control and energy dissipation purposes in different dynamical systems to adjust the damping components and improve the performance while consume a small amount of energy. In this regard, different semi-active control techniques including Skyhook, Ground hook and so on are explored and compared mathematically and experimentally. In each particular case, the root mean square (RMS) values of the first and second cart displacement, velocity and acceleration levels are determined and compared. Finally, the results have shown significant improvement in semiactive control strategies, up to $20 \%$, in comparison with the corresponding optimized passive case [5].
Byron Bloch et.al (1998), large truck crashes account for a substantial portion of the fatalities and serious injuries occurring in modern passenger vehicles designed for good frontal crash protection. Incompatibilities in mass, stiffness, and ground clearance present challenges in improving crash outcomes for passenger vehicle occupants. A recent Insurance Institute for Highway Safety study of cases from the Large Truck Crash Causation Study (LTCCS) found that rear underride guards meeting US federal requirements still can allow severe passenger vehicle underride, often resulting in serious or fatal injury. The study identified patterns of real-world guard failure, but the impact speeds necessary to produce these failures could not be determined. Also, due to the LTCCS case selection requirement that each crash produce an injury, differences among the large number of guard designs and resulting crash performance and injury risk could not be compared. The current study used a series of six crash tests to investigate these issues [6].

\section{BLOCK DIAGRAM OF SET UP}

\section{Inner Member:}

This member should attach to the chassis of heavy duty vehicle through the projections made by I section member. So that the height of this safety impact guard from ground level should reduce. So our first aim should be completed i.e. reduce the ground clearance of safety impact guard to avoid under ride crashes. As this member is attached to chassis of heavy duty vehicle so the effect of impact is negligible on chassis. Therefore the Inner member and chassis act as rigid member. The overall effect of impact on heavy duty vehicle is negligible.

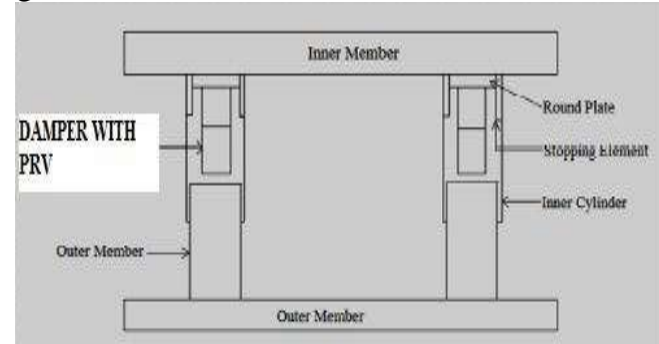

Fig. 4 Block Diagram of Safety Impact Guard with PRV Based Damper

Inner Cylinder:

This attached to the inner member. These consist of crushing damper element, round plate, pressure relief valve. The diameter of inner cylinder should be more than the outer cylinder. So the outer cylinder can play sliding motion in inner cylinder when impact comes

Pressure Relief Valve:

Damper is the element which displaces after impact 


\section{International Journal of Engineering Applied Sciences and Technology, 2019 \\ Vol. 4, Issue 5, ISSN No. 2455-2143, Pages 202-209 \\ Published Online September 2019 in IJEAST (http://www.ijeast.com)}

comes from the outer element. Damper element is collapsible, it employs heavy duty spring that absorbs the primary impact energy which is accounted to be 30 $\%$ of the total impact energy, and then the rest amount of energy is dissipated with help of pressure relief valve. Due to displacement effect the impact force will destroyed as well as the effect of this damper will temporarily collapse as it plays important role in destruction of impact energy. According to impact force to sustain this force specifications of the damper and inner element can be vary.

\section{Round Plate:}

Round plate should place inside inner cylinder as back support. Due to round plate strength of inner member \& inner cylinder increases also restricts the motion of outer cylinder going besides the inner member.

\section{Stopping Element:}

Stopping element is added in inner cylinder to stop the motion of outer cylinder.

When impact force acts on the outer member then it pushes outer cylinder which causes Sliding motion between inner and outer cylinder. This impact force very large therefore to stop motion this stopping element is added.

\section{Outer Member:}

The outer member is the element on which the impact force acts or the passenger vehicle back to the heavy vehicle crashes on this outer member.

\section{Outer Cylinder:}

This is attached to the outer member. The impact force is transmitted through the outer cylinder to the damper element. The diameter of this outer cylinder is less than the inner cylinder.

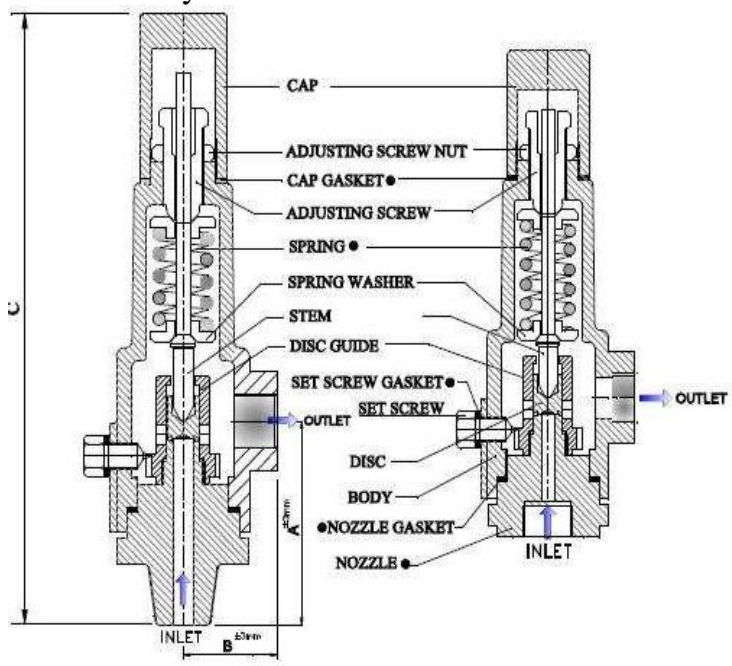

Fig.5 PRV Assembly

\section{Function of PRV}

The function of a pressure relief valve is to protect pressure vessels, piping systems, and other equipment from pressures exceeding their design pressure by more than a fixed predetermined amount. The permissible amount of overpressure is covered by various codes and is a function of the type of equipment and the conditions causing the overpressure.

It is not the purpose of a pressure relief valve to control or regulate the pressure in the vessel or system that the valve protects, and it does not take the place of a control or regulating valve. The aim of safety systems in processing plants is to prevent damage to equipment, avoid injury to personnel and to eliminate any risks of compromising the welfare of the community at large and the environment. Proper sizing, selection, manufacture, assembly, test, installation, and maintenance of a pressure relief valve are critical to obtaining maximum protection.

\section{DESIGN OF PARTS}

Considering the following heavy duty vehicle and passenger vehicle for design of parts:

Heavy Duty Vehicle: TATA LPS 3516 EX Passenger Vehicle: Hyundai i10

From the above specification and dimension we can design some member of safety impact guard. In this project manufacturing, testing and trails are not included.

I. Calculation of Impact Force:

In mechanics, an impact is a high force or shock applied over a short time period When two or more bodies collide.

Impact Force $=$ Kinetic Energy/ Impact Distance....(1)

For this project impact distance is consider as $0.5 \mathrm{~m}$.

Kinetic Energy of a passenger vehicle is calculated as:

Kinetic Energy $=\frac{1}{2} \times m v^{2}$

Where,

$\mathrm{m}=$ mass of passenger vehicle, $\mathrm{v}=$ velocity of passenger vehicle

For sustaining all impact energy we have to consider maximum impact force acting on heavy duty vehicle.

For calculation of maximum impact force, consider maximum velocity of passenger vehicle travelling on Indian highway is $80 \mathrm{~km} / \mathrm{hr}$. i.e. $22.23 \mathrm{~m} / \mathrm{sec}$.

We consider the passenger vehicle mass i.e. Hyundai i10 $1040 \mathrm{~kg}$. Therefore the eq.n. (2) Becomes:

$\mathrm{K} . \mathrm{E}=\frac{1}{2} \times 1040 \times 22.23^{2}=256.969 \times 10^{3} \mathrm{~J}$

Therefore above equation (1) becomes:

Impact Force $=\frac{256.969 \times 10^{3}}{0.5}=513.939 \mathrm{KN}$

\section{SIZING AND SELECTION OF RELIEF VALVE} Given:

Fluid: No. Oil (hydrol-32) 


\section{International Journal of Engineering Applied Sciences and Technology, 2019 \\ Vol. 4, Issue 5, ISSN No. 2455-2143, Pages 202-209 \\ Published Online September 2019 in IJEAST (http://www.ijeast.com)}

Set Pressure: 115 psig

Overpressure: $10 \%$

Back Pressure: Atmospheric

Inlet relieving Temperature: $60^{\circ} \mathrm{F}$

Dynamic Viscosity: $850 \mathrm{Cp}$

Specific Gravity: 0.993

Finding the correct size for standard orifice to meet the given requirements

(1) Since the overpressure is $<25 \%$, determine the correction factor

From Equation,

$=0.0014(\%$ overpressure $) 2+0.073(\%$ overpressure $)$

$$
+0.016
$$

$=0.0014(10) 2+0.073(10)+0.016+0.61$

$=0.61$

Operating flow rate $=18 \mathrm{gal} / \mathrm{min}$ Hence,

$\mathrm{A}=\frac{18 \times \sqrt{0.993}}{27.2 \times 0.61 \times 1 \times 1 \times \sqrt{115}}$

$\mathrm{A}=0.1008$ sq. In

$\mathrm{A}=\frac{\pi}{4} \times D^{4}$

$\mathrm{D}=\sqrt{\frac{(0.1008 \times 4)}{3.142}}$

$=0.3582$ inch

Thus diameter of orifice $=9 \mathrm{~mm}$

\section{DESIGN OF VALVE ROD}

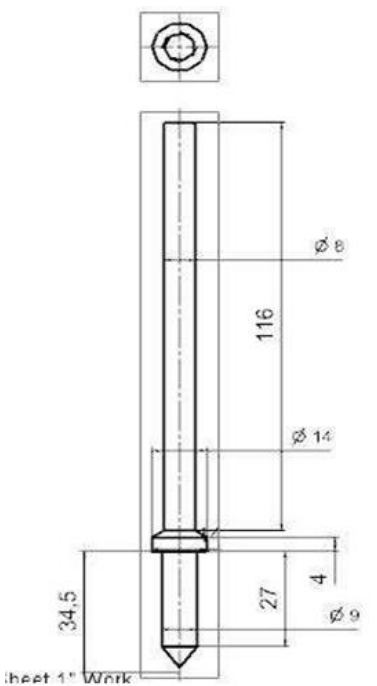

Fig. 6 Valve Rod

Material of Valve Rod: EN24

(allowable stress $=144 \mathrm{~N} / \mathrm{mm} 2$ ) Force analysis:

Pressure $=$ Force $/$ area

Force $=$ Pressure $\times$ area $=0.8 \times(\pi \times 14 \times 14) / 4$ $=1232 \mathrm{~N}$

Thus Compressive Stress $=$ Force $/$ area

$$
\begin{gathered}
=1232 / 50.2 \\
=24.54 \mathrm{~N} / \mathrm{mm} 2
\end{gathered}
$$

As the maximum stress <allowable stress therefore part is safe.

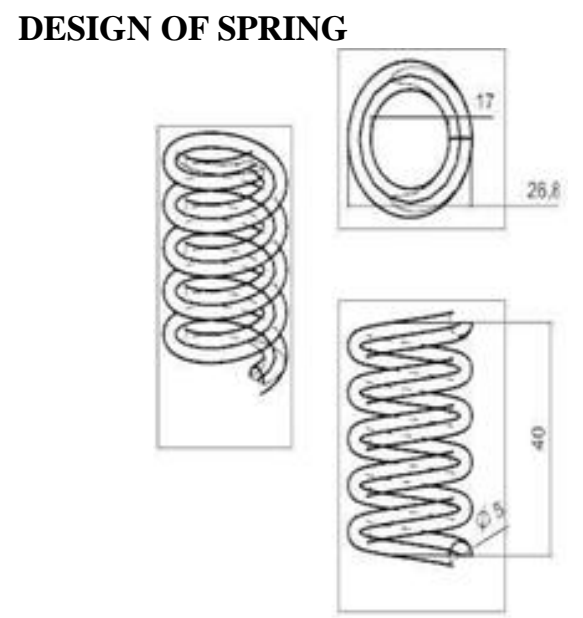

Fig.7 Spring

Theoretical Stress In Spring Of 15 N Force: plain spring

Given data

Type: Helical Compression Spring

End Condition: Both End Squared and Ground.

Rod Diameter: $5 \mathrm{~mm}$

Mean Coil Diameter: $21.8 \mathrm{~mm}$

Inner Diameter $=17 \mathrm{~mm}$

Outer Diameter $=27 \mathrm{~mm}$

Number of Turns $=5$

Free Length $=40 \mathrm{~mm}$

$\mathrm{G}=80 \times 10^{3} \mathrm{Mpa}$

\section{Calculation of Theoretical Stress: Stress In Coil ( $\sigma)$}

$\sigma=\frac{K \times 8 \times P \times D}{\pi \times d^{3}}$

Here,

$\mathrm{K}=$ Stress factor $=1.19$----calculated used spring index.

$\sigma=\underline{1.19 \times 8 \times 246.3 \times 21}$

$$
\pi \times 53^{3}
$$

$\sigma_{\text {th }}=15.6 \mathrm{~N} / \mathrm{mm}^{2}$

As $\sigma_{\text {th }}<\sigma_{\text {allowable }}$

Thus spring is safe.

\section{DISC SPRING OR BELIVELLI SPRING}

Disc springs are the best choice when your application requires loading on an axial direction. Discs can be designed as single or stacked based on the needs of our customer.

Advantages of Disc Springs include: 


\section{International Journal of Engineering Applied Sciences and Technology, 2019 \\ Vol. 4, Issue 5, ISSN No. 2455-2143, Pages 202-209 \\ Published Online September 2019 in IJEAST (http://www.ijeast.com)}

- Heavy load bearing capacity

- Space saving and low maintenance cost

- Good shock absorption and energy dissipation

- High fatigue life and tensile strength

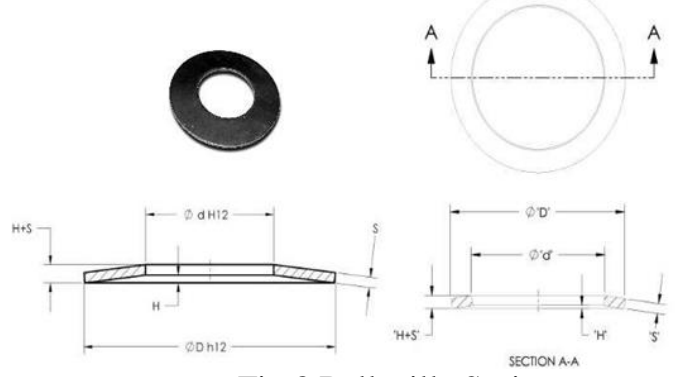

Fig.8 Belleville Spring

\section{FABRICATION OF SAFETY IMPACT GUARD}

The setup of safety impact guard with pressure relief valve is as shown in the fig. In the setup, the impact force of collision is applied by the weight attached at the top of the setup. The weight consider in this project is $3 \mathrm{~kg}$. The damper is arranged at the bottom. Damper consists of the outer and inner cylinder, spring and the pressure relief valve. The damper is located between the outer and the inner member. The weight is release from the height on the outer member as the impact force of collision. So the potential energy of the weight is converted into the kinetic energy when the weight is released from the height. The outer member is displaced by the weight. Then this motion is transmitted through the outer cylinder to the damper.

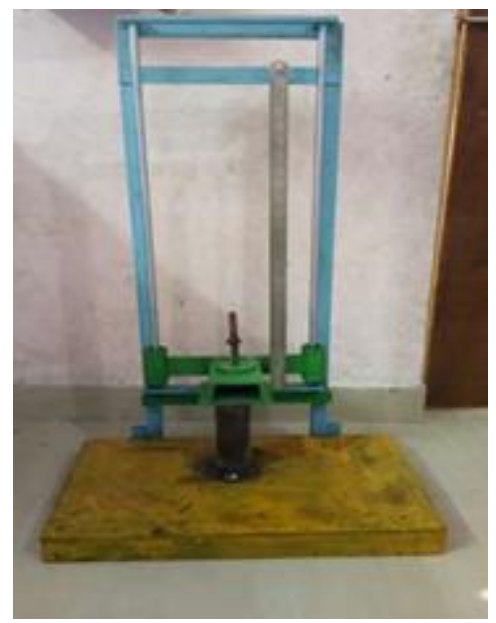

Fig. 9 Safety Guard Set Up

Damper consists of the spring which is then deflected and pressure relief valve is actuated. The pressure relief valve is operated at the set pressure and absorbs the impact force by releasing the oil. The energy absorbed by the damper is then calculated by finding the deflection of the outer member. The deflection is calculated by taking the difference between $\mathrm{H} 1$ and $\mathrm{H} 2$. Then the input energy is the kinetic energy and output is the energy absorbed by the damper.

\section{CONCLUSION}

Based on investigation of previous literature and working model developed following conclusions are drawn as follows:

- Safety impact guard with pressure relief valve is used as a safety instruments in heavy duty vehicle to avoid the rear collision.

- Safety impact guard with pressure relief valve can be use by just replacing the oil in case of high impact.

- It also provides safety against underride crashes which is cause due to passenger vehicle collides with the heavy duty vehicle.

- By implementing this safety impact guard passenger life present in passenger cars can be safe.

Thus the rear impact safety guard is designed and fabricated. This impact guard saves the life of human being by avoiding accidents. It is also improve the life of vehicles.

\section{ACKNOWLEDGEMENT}

The authors wish to thank Head of Dept. Mechanical, Principal of Dr. Vitthalrao Vikhe Patil College of Engineering Ahmednagar for their support during the course of this work.

\section{REFERENCES}

[1] Dixit Neha S., Chandak Ajay G., 2014. 'Design, Modelling \& Analysis of Safety Impact Guard for Heavy Duty Vehicle' International Journal of Innovative Research in Advanced Engineering (IJIRAE) ISSN: 2349-2163 Volume 1 Issue 6.

[2] Srinivas Bairy, 2016, 'Reduction in the Impact Force on a vehicle using Spring Damper System' International Journal of Engineering Research and General Science, Volume 4, Issue 1.

[3] Ricardo José, Mariolani Lenzi, 2013, 'Development of new underride guards for enhancement of compatibility between trucks and cars' State University of Campinas Brazil, Paper Number 425.

[4] Hassaan Galal A., 2014, 'Optimal design of an anti-accidents vehicle buffer' International Journal of 


\section{International Journal of Engineering Applied Sciences and Technology, 2019 \\ Vol. 4, Issue 5, ISSN No. 2455-2143, Pages 202-209 \\ Published Online September 2019 in IJEAST (http://www.ijeast.com)}

Research in Engineering \& Technology (IMPACT:

IJRET) ISSN (E): 2321-8843; ISSN (P): 2347-4599

Vol. 2, Issue 5, pp. 161-168.

[5] Geldhof Geoffrey, 2013, 'Semi ACTIVE Vibration Dynamics Control of Multi Cart Systems Using a Magneto rheological Damper', Chalmers University of Technology Goteborg, Sweden, Master's thesis 2013:21

[6] Bloch Byron,Otto Louis, Schmutzler Faber,1998, 'Improved Crashworthy Designs for truck Underride Guards' 16th International Technical Conference on the Enhanced Safety of Vehicles in Windsor, Ontario, Canada.

[7] Bhandari V. B., 2007, Design of Machine Elemenets, McGraw-Hill Education Pvt. Ltd.

[8] Hasan Muhamad Abid, Eida Nadirah Roslin, Rifqi Irzuan Bin Abdul Jalal, 2019, Performance of Rear under -ride Protection Device (RUPD) during car to heavy truck rear impact, International Journal of Engineering and Technology (IJEAT), vol. 8, Issue. 6.

[9] Cappello F., Ingrassia T. \& Nigrelli V., 2008, Design of a new high energy rear underrun protective device, High Performance Structures and Materials, Vol. 4. DOI: 10.2495/HPSM080341.

[10] Sen Prakash Kumar, Bohidar Shailendra Kumar, Jaiswal Rohit, Anant Rajesh, 2014, Optimisation\&Development of Vehicle Rear Underrun protection devices in Heavy Vehicle (RUPD) for regulative Load Cases, International Journal for innovative research in science \& Technology, Vol. 1. 